\title{
Effect of oral injection of tramadol, sildenafil and combined of tramadol and sildenafil on serum testosterone level for Wistar breed male rats.
}

\author{
Rabie S. Farag1 ,Mohamed El Nawawy1, Wael M. Fathy2* and Hamada Atiaa2. \\ 1Chemistry department, Faculty of Science, Al-Azhar University, Cairo, Egypt and \\ 2Analytical Toxicology Laboratory, Forensic Medicine Authority, Cairo, Egypt .
}

\begin{abstract}
:
Introduction:Testosterone is the main sexual hormone in human males, and has a pharmacological effect on the physiology of sexual function. It is known that suppression of testosterone in eugonadal adult males leads to reduced sexual desire and activity, and may result in erectile dysfunction. Tramadol is rapidly and almost completely absorbed after oral administration but its absolute bioavailability is only $65-70 \%$ due to first-pass metabolism. Sildenafil citrate is a water soluble citrate salt that was firstly synthesized by Pfizer in United Kingdom to treat hypertension and angina pectoris. Interestingly, this drug exhibited a different pharmacological effect, a marked penile erection, and became the first-line treatment option to erectile dysfunction. Aim of the work :the main work goal of this search was to measure and compare between mean serum testosterone concentrations after oral injection of tramadol, sildenafil , and combination of tramadol and sildenafil beside healthy subjects.Investigated Parameter: quantitative analysis of Free Testosterone ELISA Kit in serum by The Calbiotech, Inc. 10461 Austin Dr, Spring Valley, CA U.S.A., depending on McCann, D., et al 1985. Results In the present study, the results of GT group revealed that administration of tramadol $50 \mathrm{mg} / \mathrm{Kg} / \mathrm{day}$ for 10,20 days and 30 days indicated that the measured testosterone levels were lower than the (GC) control group, and the decrease in testosterone mean concentrations in GT3, than GT2, than GT1. In our research GS group administration of sildenafil 50 $\mathrm{mg} / \mathrm{Kg} /$ day for 10, 20 and 30 days groups indicated that increase testosterone levels than that in control GC group, and there was an increase in testosterone mean concentrations in GS3, than GS2, than GS1. The present study reveled in GT\&S administration of tramadol $50 \mathrm{mg} / \mathrm{Kg} /$ day combined with sildenafil $50 \mathrm{mg} / \mathrm{Kg} /$ day that the mean serum testosterone concentrations in (GT\&S1), (GT\&S2) and (GT\&S3), were decrease than in the mean serum testosterone concentrations (GC), but this decrease in the mean serum testosterone concentrations in (GT\&S1), (GT\&S2) and (GT\&S3), were quite higher than mean serum testosterone concentrations in GT1, GT2, and GT3, also and there were a decrease in mean testosterone mean concentrations in (GT\&S3) than that in (GT\&S2) and (GT\&S1) conclusion: tramadol administration decrease testosterone levels, while sildenafil increase testosterone levels, while the combination between tramadol \& sildenafil decrease testosterone levels.
\end{abstract}

Key words: tramadol, sildenafil, and testosterone.

\section{Council for Innovative Research}

Peer Review Research Publishing System

\section{Journal: INTERNATIONAL JOURNAL OF COMPUTERS \& TECHNOLOGY}

Vol 11, No. 9

editor@cirworld.com

www.cirworld.com, member.cirworld.com 


\section{Introduction:}

Testosterone is the main sexual hormone in human males, and has a pharmacological effect on the physiology of sexual function. It is known that suppression of testosterone in eugonadal adult males leads to reduced sexual desire and activity, and may result in erectile dysfunction(1). Tramadol hydrochloride, ( \pm )-Trans-2-[(dimethylamino) methyl]-1-(3methoxyphenyl) cyclohexanol, is a centrally-acting analgesic used in the treatment of mild to moderate pain (2). Its therapeutic plasma concentration range is $100-300 \mathrm{ng} / \mathrm{ml}$ (3). Tramadol is rapidly and almost completely absorbed after oral administration but its absolute bioavailability is only $65-70 \%$ due to first-pass metabolism (4). The metabolism of tramadol in human is mediated bycytochrome P4502D6 (CYP2D6) to O-desmethyltramadol ODT) and $\mathrm{N}$ desmethyltramadol (NDT). ODT is pharmacologically active and contributes to the analgesic efficacy of tramadol (5).Sildenafil used for the treatment of erectile dysfunction, is one of the most popular and widely used drugs in Egypt. Sildenafil citrate (Viagra), have become one of the most prescribed and abused pharmaceutical (6). Sildenafil citrate is a water soluble citrate salt that was firstly synthesized by Pfizer in United Kingdom to treat hypertension and angina pectoris. Interestingly, this drug exhibited a different pharmacological effect, a marked penile erection, and became the first-line treatment option to erectile dysfunction $(7,8)$.

\section{Aim of the work:}

Recently, drug abusers were taking tramadol and Sildenafil for sexual issues, so because of that, the main work goal of this search was to measure and compare between mean serum testosterone concentrations after oral injection of tramadol, sildenafil , and combination of tramadol and sildenafil beside healthy subjects.

\section{Material and Method:}

\section{Subjects Selection}

The present study comprises the following groups:

(A) Tramadol group (GT), consists of three sub groups:

(1) (GT1) Ten healthy Wistar breed male rats weighing 130 to $150 \mathrm{~g}$ were injected orally with50 $\mathrm{mg} / \mathrm{kg}$ of tramadol for ten days.

(2) (GT2) Ten healthy Wistar breed male rats weighing 130 to $150 \mathrm{~g}$ were injected orallywith50 $\mathrm{mg} / \mathrm{kg}$ of tramadol for twenty days.

(3) (GT3) Ten healthy Wistar breed male rats weighing 130 to $150 \mathrm{~g}$ were injected orally with50 mg/kg of tramadol for thirty days.

(B) Sildenafil group (GS), consists of three sub groups:

(1) GS1) Ten healthy Wistar breed male rats weighing 130 to $150 \mathrm{~g}$ were injected orally with50 $\mathrm{mg} / \mathrm{kg}$ of sildenafil for ten days.

(2) (GS2) Ten healthy Wistar breed male rats weighing 130 to $150 \mathrm{~g}$ were injected orally with50 mg/kg of sildenafil for twenty days.

(3) (GS3) Ten healthy Wistar breed male rats weighing 130 to $150 \mathrm{~g}$ were injected orally with50 mg/kg of sildenafil for thirty days.

(C) Tramadol \& Sildenafil group (GT\&S), consists of three sub groups:

(1) (GT1) Ten healthy Wistar breed male rats weighing 130 to $150 \mathrm{~g}$ were injected orally with50 mg/kg of tramadol\& sildenafil for ten days.

(2) (GT2) Ten healthy Wistar breed male rats weighing 130 to $150 \mathrm{~g}$ were injected orally with50 mg/kg of tramadol sildenafil for twenty days.

(3) (GT3) Ten healthy healthy Wistar breed male rats weighing 130 to $150 \mathrm{~g}$ were injected orally with50 mg/kg of tramadol \& sildenafil for thirty days.

(D) Control group (GC), ten healthy Wistar breed male rats weighing 130 to $150 \mathrm{~g}$ as control.

All healthy Wistar breed male rats were collected from the Animal House in the National Institution for Research, Cairo, Egypt.

Materials and Methods:

a. Investigated Parameter: quantitative analysis of Free Testosterone ELISA Kit in serum by The Calbiotech, Inc. 10461 Austin Dr, Spring Valley, CA U.S.A., depending on McCann, D., et al 1985(9).

The biochemical parameter was analyzed immediately.

b. Subject Specimens

(1) Serum: For the assay of quantitative analysis of Free Testosterone. 
Blood samples were collected at 8:00 AM O'clock in clean dry plastic tubes, left to clot for 20 minutes at $37^{\circ} \mathrm{C}$ and then centrifuged at $3000 \mathrm{rpm}$ for 15 minutes.

\section{c. Chemicals}

All chemicals used for enzymatic activities and biochemical analysis

were supplied from Sigma, Fulka, and Boehringer Mannheim products.

\section{Quantitative Measurements of Free Testosterone Hormone}

Quantitative analysis of Free Testosterone ELISA Kit in serum by The Calbiotech, Inc. 10461 Austin Dr, Spring Valley, CA U.S.A., depending on McCann, D., et al 1985.

\section{Principle:}

The CBI Free Testosterone ELISA KIT is based on the principle of competitive binding. The microtiter wells are coated with an antibody directed towards a unique antigenic site on a Testosterone molecule. An aliquot of sample containing endogenous Free Testosterone is incubated in the coated well with enzyme conjugate, which is an anti-Free Testosterone antiserum conjugated with horseradish peroxidase. After incubation the unbound conjugate is washed off with distilled water. The amount of bound peroxidase is proportional to the concentration of Free Testosterone in the sample. Having added the substrate solution, the intensity of colour developed is proportional to the concentration of Free Testosterone in the sample.

\section{Reagent:}

1. Microwells coated with anti-testosterone $\lg \mathrm{G} 12 \times 8 \times 1$

2. Standard (0-5): (6 vials ready to use) $1 \mathrm{ml}$

3. Enzyme Conjugate (ready to use) $15 \mathrm{ml}$

4. TMB substrate (ready to use) $15 \mathrm{ml}$

5. Stop solution (ready to use) $15 \mathrm{ml}$

6. Wash Solution 10x Concentrated $50 \mathrm{ml}$

\section{Procedure:}

All reagents and specimens allowed coming to room temperature before use. All reagents were mixed without foaming. Once the test has been started, all steps completed without interruption.

1. Secure the desired number of Microtiterwells in the holder.

2. Dispensed 20 LI Free Testosterone Standards, controls and samples with new disposable tips into appropriate wells.

3. Dispensed 100 LI Enzyme Conjugate into each well.

4. Thoroughly mix for 10 seconds. It was important to have a complete mixing in this step.

5. Incubated for 1 hour at $37^{\circ} \mathrm{C}$.

6. Briskly shake out the contents of the wells. Rinse the wells 3 times with diluted wash solution. Strike the wells sharply on absorbent paper to remove residual water droplets.

7. Added $100 \mathrm{LI}$ of Substrate Solution to each well.

8. Incubated for 15 minutes at room temperature in the dark.

9. The enzymatic reaction was stopped by adding $100 \mathrm{LI}$ of Stop Solution to each well.

10. Read absorbance on ELISA Reader at $450 \mathrm{~nm}$ within 10 minutes after adding the stop solution.

\section{Calculation:}

1. The average absorbance values were calculated for each set of standards, controls and samples.

2. Standard curve was constructed by plotting the mean absorbance obtained from each standard against its concentration in $\mathrm{ng} / \mathrm{ml}$ with absorbance value on the vertical $(\mathrm{Y})$ axis and concentration on the horizontal $(\mathrm{X})$ axis fig (1).

3. By using the mean absorbance value for each sample the corresponding concentration of Free Testosterone was determined from the standard curve. Depending on experience and/or the availability of computer capability, other methods of data reduction may be employed.

4. Automated method: Computer programs by using cubic spline, 4 PL (4 Parameter Logistics) or Logit-Log give generally a good fit. 


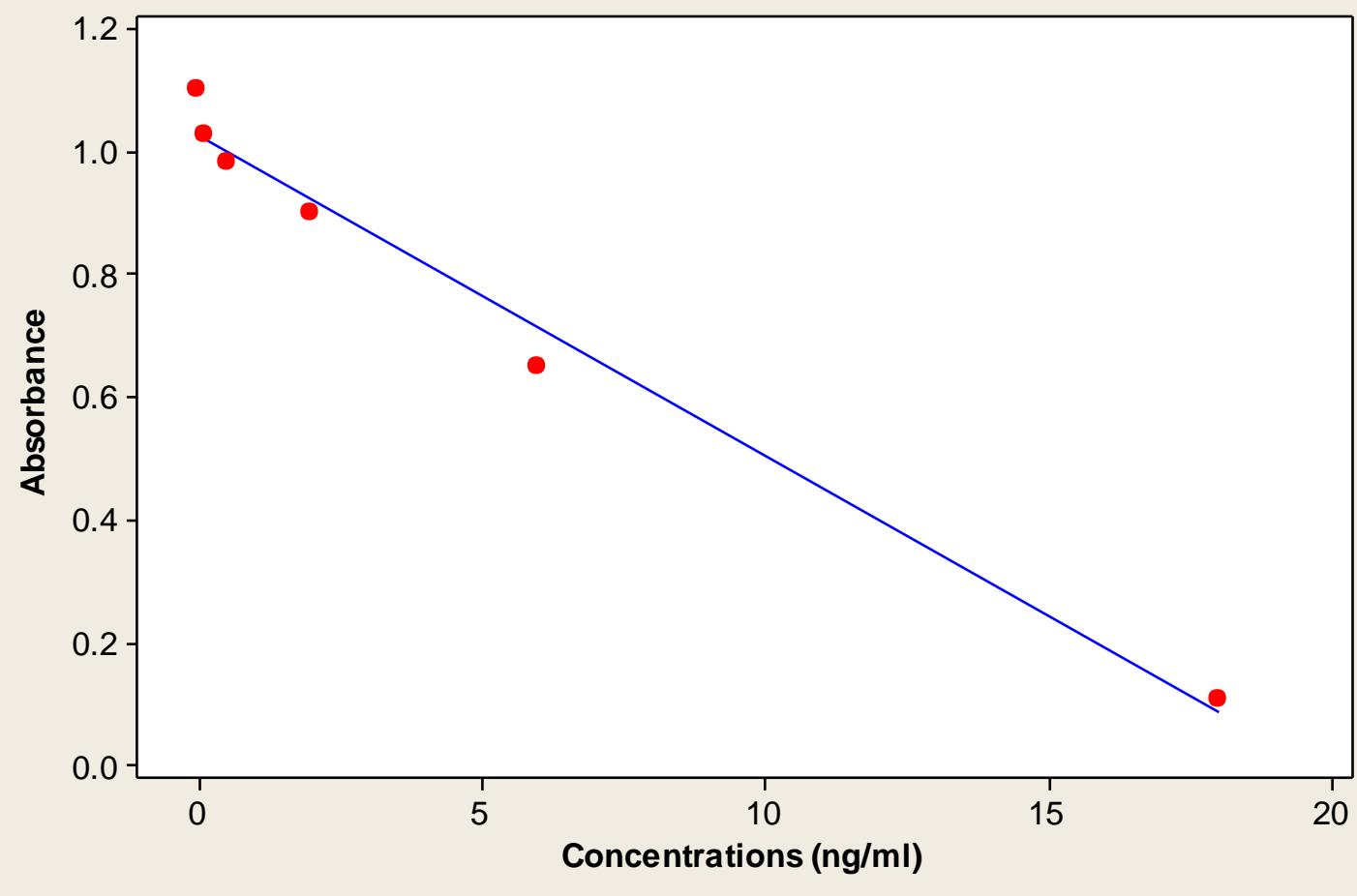

\section{Result:}

Fig (1) Standard curve of testosterone concentrations

There was a decrease in testosterone mean concentrations $(\mathrm{ng} / \mathrm{ml})($ Mean GT1 $\pm S D)(4.25 \mathrm{ng} / \mathrm{ml} \pm 0.5)$ than that in $\mathrm{GC} \pm \mathrm{SD}(5.14 \mathrm{ng} / \mathrm{ml} \pm 0.22)$, but it's statistically insignificant with $P$ value $(P>0.05)$.

In comparison between testosterone mean concentrations $(\mathrm{ng} / \mathrm{ml}) \pm$ standard deviation was values in $\mathrm{GC} \pm \mathrm{SD}(5.14$ $\mathrm{ng} / \mathrm{ml} \pm 0.22)$, and (Mean GT2 \pm SD) $(3.45 \mathrm{ng} / \mathrm{ml} \pm 0.33$ ) found a significant mean difference and significant $P$ value $(\mathrm{P}<0.05)$.

Statistical data showed a significant mean difference and significant $P$ value $(P<0.05)$ in comparison between $G C \pm S D$ $(5.14 \mathrm{ng} / \mathrm{ml} \pm 0.22)$ values in and (Mean GT3 $\pm S D)(2.93 \mathrm{ng} / \mathrm{ml} \pm 0.3)$.

There was a decrease in testosterone mean concentrations ( $\mathrm{ng} / \mathrm{ml}) \pm$ standard deviation in GT3, than GT2, than GT1, and it was statistically significant with $(P<0.05)$.

There was Testosterone mean concentrations ( $\mathrm{ng} / \mathrm{ml}) \pm$ standard deviation (Mean GS1 $\pm \mathrm{SD}$ ) was $(5.13 \mathrm{ng} / \mathrm{ml} \pm 0.48)$ after 10days of oral injection of $50 \mathrm{mg} / \mathrm{day} / \mathrm{kg}$ of sildenafil. Testosterone mean concentrations (ng/ml) (Mean GS2 $\pm S D$ ) was $(6.13 \mathrm{ng} / \mathrm{ml} \pm 0.63)$ after 20days of oral injection of $50 \mathrm{mg} / \mathrm{day} / \mathrm{kg}$ of sildenafil, and after 30days of oral injection of $50 \mathrm{mg} /$ day $/ \mathrm{kg}$ of sildenafil testosterone mean concentrations $(\mathrm{ng} / \mathrm{ml})$ (Mean GS3 $\pm S D)$ was $(6.25 \mathrm{ng} / \mathrm{ml} \pm 0.96)$.

The mean serum testosterone concentrations in (GS1) was almost the same as mean serum testosterone concentrations in (GC), but in (GS2), and (GS3) were elevated than in mean serum testosterone concentrations in (GC) but it was statistically insignificant.

There was an increase in testosterone mean concentrations ( $\mathrm{ng} / \mathrm{ml}) \pm$ standard deviation in GS3, than GS2, than GS1, and it was statistically insignificant with $(P>0.05)$.

After 10days of oral injection of $50 \mathrm{mg} / \mathrm{day} / \mathrm{kg}$ of mixture of sildenafil and tramadol, serum testosterone mean concentrations $(\mathrm{ng} / \mathrm{ml}) \pm$ standard deviation (Mean GT\&S1 $\pm S D)$ was $(5.0 \mathrm{ng} / \mathrm{ml} \pm 0.35)$, testosterone mean concentrations $(\mathrm{ng} / \mathrm{ml}$ ) (Mean GT\&S2 $\pm S D$ ) was $(4.6 \mathrm{ng} / \mathrm{ml} \pm 0.31$ ) after 20days of oral injection of $50 \mathrm{mg} / \mathrm{day} / \mathrm{kg}$ of mixture of sildenafil and tramadols, and after 30 days of oral injection of $50 \mathrm{mg} /$ day $/ \mathrm{kg}$ of mixture of sildenafil and tramadol, testosterone mean concentrations $(\mathrm{ng} / \mathrm{ml}$ ) (Mean GT\&S3 $\pm S D)$ was $(4.26 \mathrm{ng} / \mathrm{ml} \pm 0.28)$.

The mean serum testosterone concentrations in (GT\&S1), (GT\&S2) and (GT\&S3), were decrease than in the mean serum testosterone concentrations (GC).

There was a decrease in mean testosterone mean concentrations ( $\mathrm{ng} / \mathrm{ml}$ ) in GT\&S3) than that in (GT\&S2) and (GT\&S1).but it's statistically insignificant with $P$ value $(P>0.05)$. 
Table (1): Mean of testosterone concentrations ( $\mathrm{ng} / \mathrm{ml}) \pm S D$ in all groups

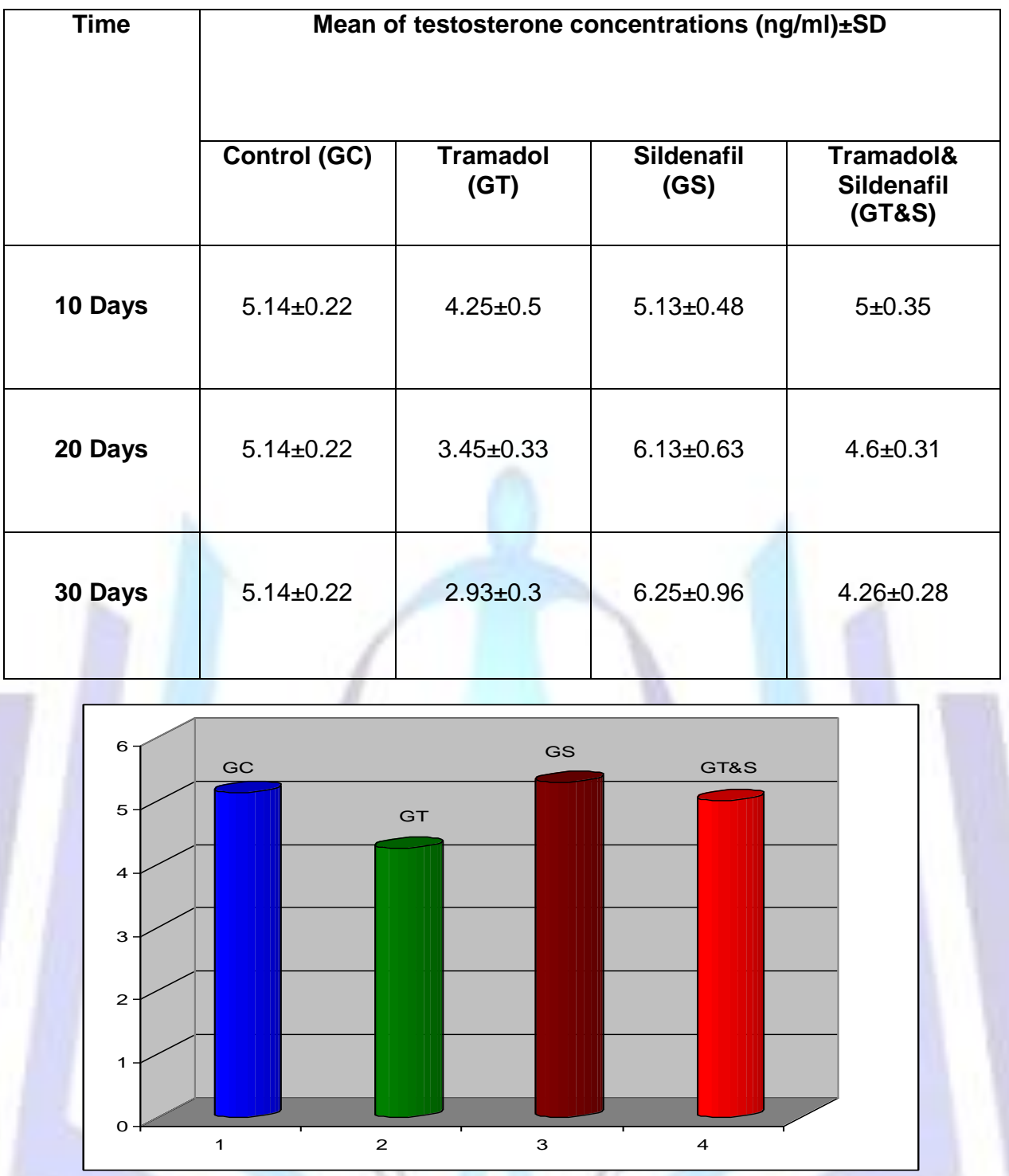

Fig (2) Testesterone levels after 10 days of oral injection.

GC; control group,GT: tramadol group,GS: sildenafil group,GS\&T: tramadol \& sildenafil group

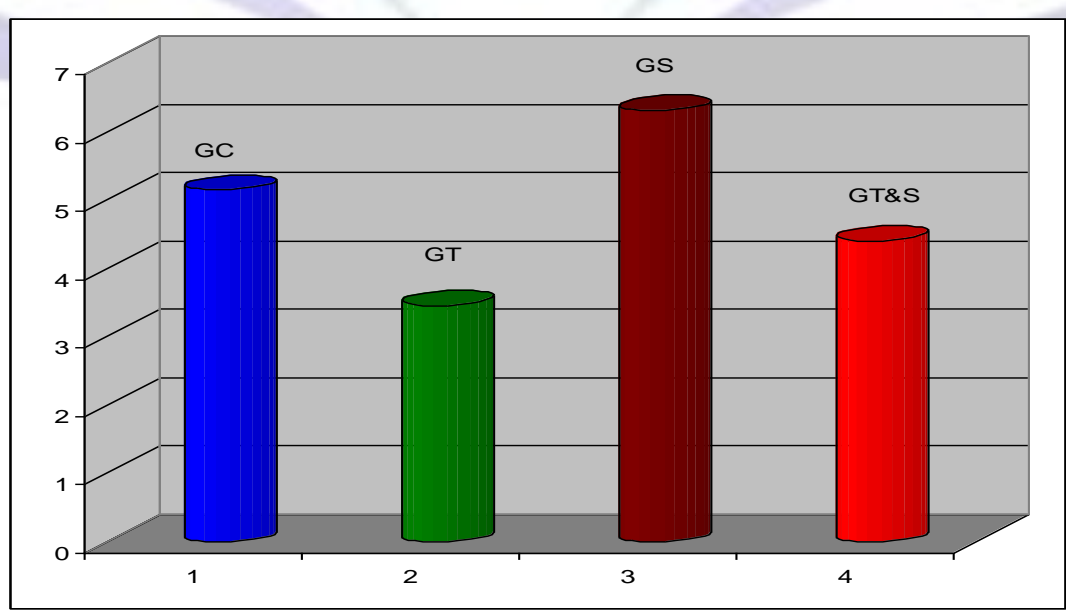

Fig (3) Testesterone levels after 20 days of oral injection.

GC; control group,GT: tramadol group,GS: sildenafil group,GS\&T: tramadol \& sildenafil group 


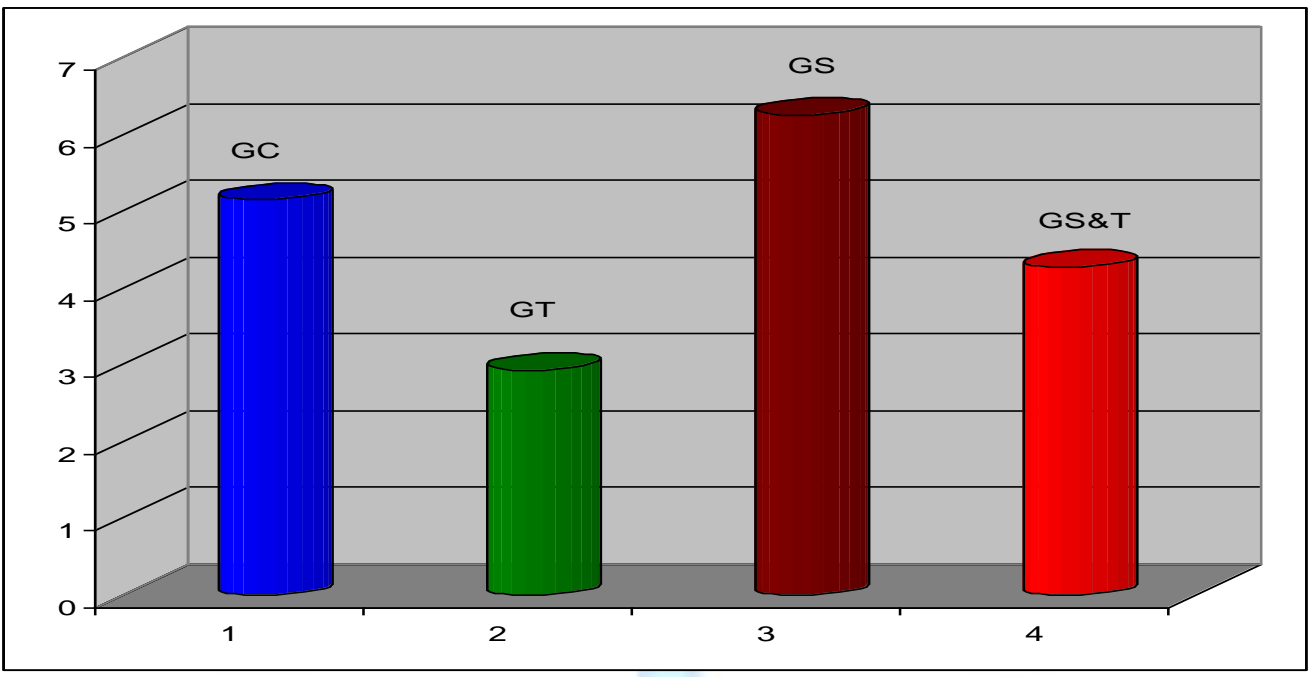

Fig (4) Testesterone levels after 30 days of oral injection.

GC; control group,GT: tramadol group,GS: sildenafil group,GS\&T: tramadol \& sildenafil group

In [GT], statistical analysis revealed, significant inversely correlation between serum testosterone concentrations and times by days, with $P$ values $(P<0.05) S=0.114310 \quad R-S q=98.5 \% \quad R-S q(\operatorname{adj})=97.0 \% \quad$ fig (5)

In [GS], statistical analysis revealed, insignificant correlation between serum testosterone concentrations and times by days, with $P$ values $(P>0.05)$, with $S=0.357217 \quad R-S q=83.2 \% \quad R-S q(\operatorname{adj})=66.4 \%$, fig $(6)$

In [GT\&S], statistical analysis revealed, significant inversely correlation between serum testosterone concentrations and times by days, with $P$ values $(P<0.05) S=0.0244949 \quad R-S q=99.8 \% R-S q(\operatorname{adj})=99.6 \%$ fig $(7)$.

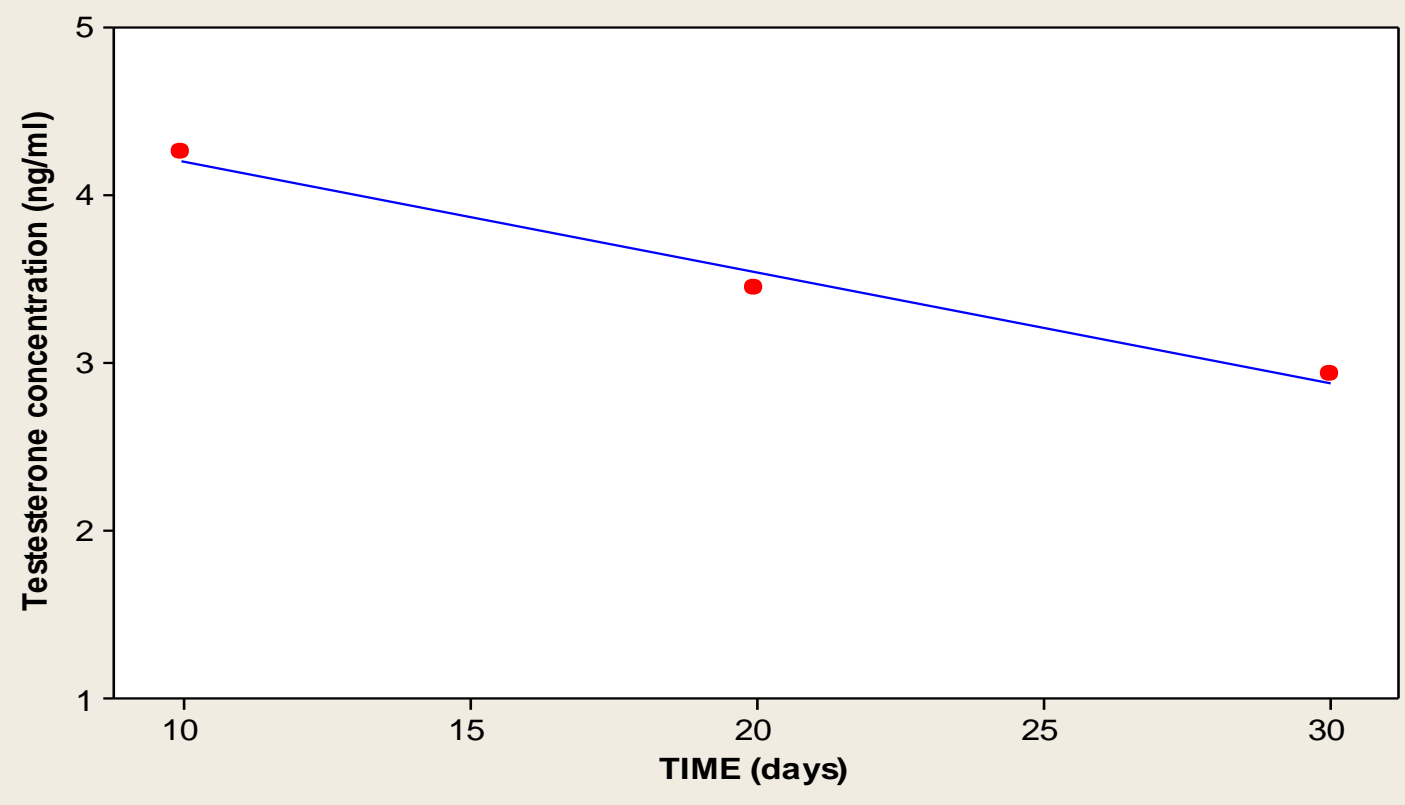

Fig (5) Effect of oral injection $50 \mathrm{mg} / \mathrm{kg}$ of tramadol on testerone levels. 


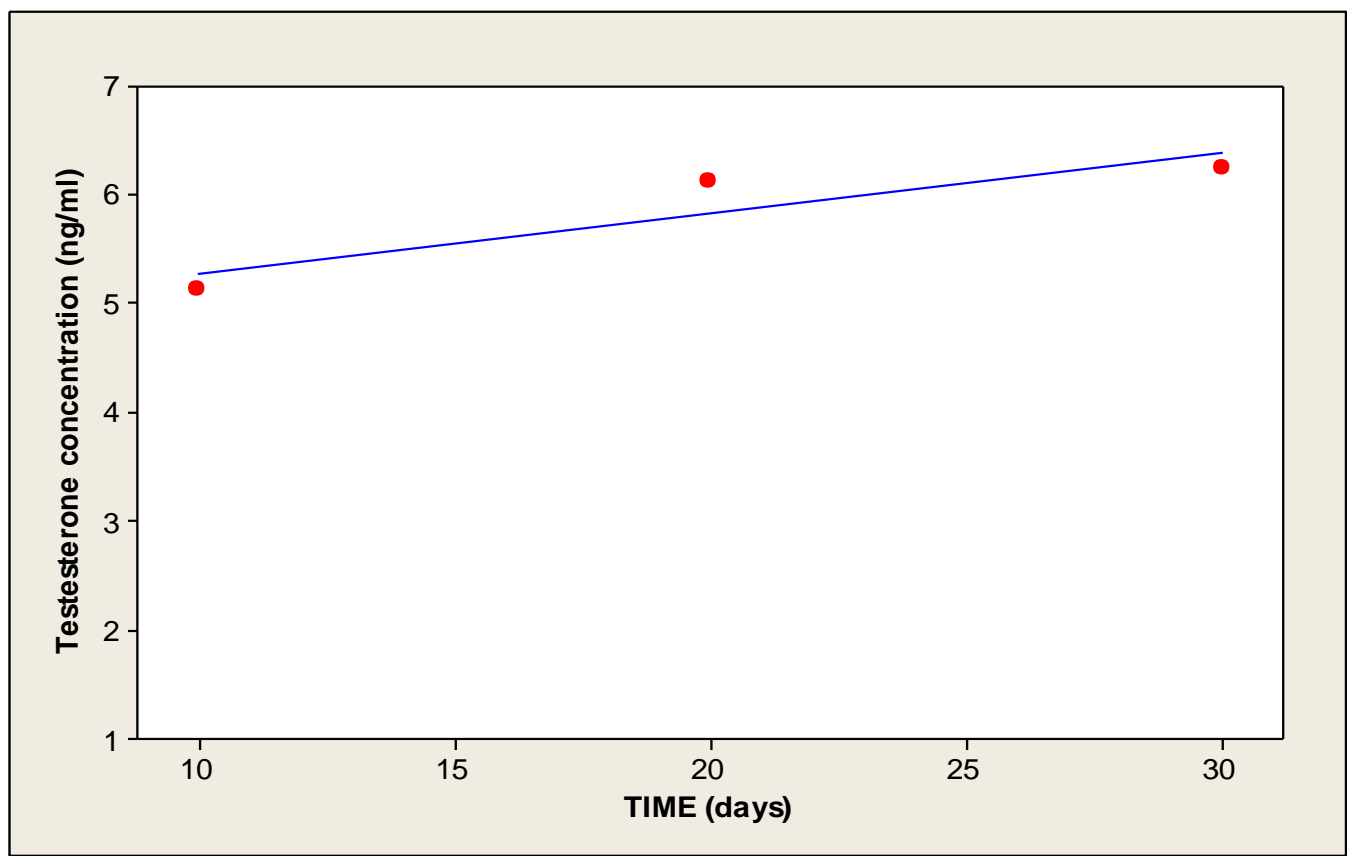

Fig (6) Effect of oral injection $50 \mathrm{mg} / \mathrm{kg}$ of sildenafil on testerone levels.

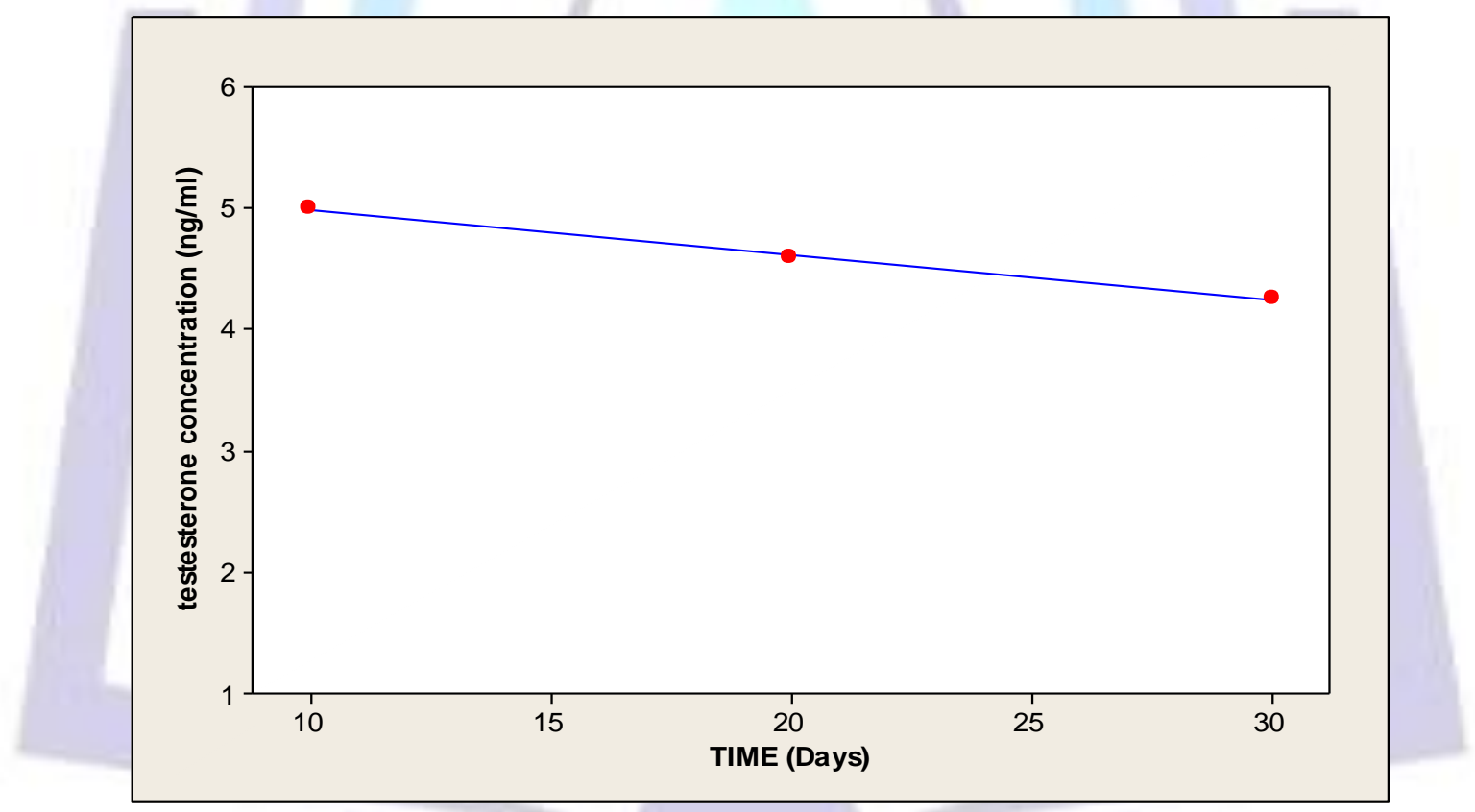

Fig (7) Effect of oral injection $50 \mathrm{mg} / \mathrm{kg}$ of tramadol and $50 \mathrm{mg} / \mathrm{kg}$ of sildenafil on testerone levels.

\section{Discussion}

In the present study, the results of GT group revealed that administration of tramadol $50 \mathrm{mg} / \mathrm{Kg} / \mathrm{day}$ for 10,20 days and 30 days indicated that the measured testosterone levels were lower than the (GC) control group, and the decrease in testosterone mean concentrations in GT3, than GT2, than GT1. The hormonal effects of opioid usage affect both men and women and have been documented during oral consumption $(10,12-16)$. Testosterone levels are typically lowered $1-4$ hours after acute administration of opioids (14) and return to normal levels within 24 hours of stopping the opioid (17). Chronic administration of opioids for nonmalignant pain result in tonic decreases in both total (TT) and free (FT) testosterone levels in an apparent dose-dependent fashion $(10,16)$. Also, it is not entirely clear that reduced testosterone directly contributes to sexual dysfunction.

These results may be due to marked decline in nitric oxide synthetase (NOS) activity and protein expression two factors important for proper erectile function. Because of tramadol consider as synthetic opioid, and binds to the $\mu$-opioid receptor, most reports suggest that, the analgesic activity and other clinical effects of tramadol are a result of opioid and non-opioid mechanisms. and the effects of opioid compounds on hormonal function is now fairly well understood and has been termed opioid endocrinopathy $(\mathrm{OE})$ or, in the case of androgen hormones, opioid-induced androgen deficiency (OPIAD). 
In our research GS group administration of sildenafil $50 \mathrm{mg} / \mathrm{Kg} /$ day for 10,20 and 30 days groups indicated that increase testosterone levels than that in control GC group, and there was an increase in testosterone mean concentrations in GS3, than GS2, than GS1.

This result may be due to the phosphodiesterase type 5 (PDE5)- inhibitor, Sildenafil, increase cyclic guanosine monophosphate (cGMP) system on steroidogenesis that can be affect particularly, in the testis, this cyclic nucleotide is involved in spermatozoa motility, development of testicular germ cells, relaxation of peritubular lamina propria cells, testosterone production in Leydig cells and dilatation of testicular blood vessels. So, increased testosterone level was associated with sildenafil administration, likely ascribable to a direct effect on the testis.

The present study reveled in GT\&S administration of tramadol $50 \mathrm{mg} / \mathrm{Kg} /$ day combined with sildenafil $50 \mathrm{mg} / \mathrm{Kg} / \mathrm{day}$ that the mean serum testosterone concentrations in (GT\&S1), (GT\&S2) and (GT\&S3), were decrease than in the mean serum testosterone concentrations (GC), but this decrease in the mean serum testosterone concentrations in (GT\&S1), (GT\&S2) and (GT\&S3), were quite higher than mean serum testosterone concentrations in GT1, GT2, and GT3, also and there were a decrease in mean testosterone mean concentrations in (GT\&S3) than that in (GT\&S2) and (GT\&S1),the previous results revealed that tramadol administration may has the upper hand on the effect of testosterone concentrations than that administration of sildenafil, because tramadol not only has a specific neurotransmitter effects, at the central level as $\mu$-opioid receptor agonist but also has a potentially effect caused by excessive serotonergic agonism of serotonin receptors in the central and peripheral nervous system that called serotonin syndrome (SS).

SS may develop as a result of increased serotonin synthesis, decreased serotonin metabolism, increased serotonin release, inhibition of serotonin reuptake (e.g., SSRIs), and/or direct agonism of serotonin receptors. The syndrome is most often the result of a prescription drug, overdose of causative drugs, and/or complex interactions among several drugs. Three key clinical features of this syndrome are as follows: (1) neuromuscular hyperactivity (2) autonomic hyperactivity and (3) altered mental status.

\section{Reference:}

[1] Shabsigh R. 2004.Testosterone therapy in erectile dysfunction.. The Aging Male ;7:312-318.

[2] R.B. Raffa, E. Friderichs, W. Reimann, R.P. Shank, E.E. Codd, J.L. Vaught, J. Pharmacol. Exp. Ther. 260 (1992) 275.

[3] Lewis K.S., N.H. Han.1997 .Am. J. Health Syst. Pharm. 54 : 643.

[4]. Lintz W., H. Barth, R. Becker, E. Frankus, E. 1998. Schmidt-B"othelt, Arzneimittelforschung $48: 436$.

[5]. Budd K., R. Langford 1999. Br. J. Anaesth. 82 : 493.

[6] Feldman H. A, Goldstein I, Hatzichristou D. G, Krane RJ, McKinlay JB (1994): Impotence and its medical and psychosocial correlates: results of the Massachusetts Male Aging Study. J Urol., 151: 54-61.

[7] Kalsi JS and Kell PD (2004).Update on oral treatments for male erectile dysfunction.J.Eur.Acad.Dermatol.Venereol.,18:267-274 .

[8] Uthayathas S, Karuppagounder SS, Thrash B M, Parameshwaran K, Suppiramaniam V and Dhanasekaran M (2007): Versatile effects of sildenafil: recentpharmacological applications. Pharmacol. Report, 59: 150-163.

[9] McCann D, Kirkish L 1985. Evaluation of Free Testosterone in serum. J.Clin. Immunoassay; 8:234-236.

[10] Daniell HW 2002. Hypogonadism in men consuming sustained-action oral opioids. J Pain; 3:377-384.

[11]Daniell HW 2008. Opioid endocrinopathy in women consuming prescribed sustained-action opioids for control of nonmalignant pain. J Pain; 9:28-36.

[12] Daniell HW 2006. DHEAS deficiency during consumption of sustained-action prescribed opioids: Evidence for opioidinduced inhibition of adrenal androgen production. J Pain; 7:901-907.

[13] Daniell HW, Lentz R, Mazer NA 2006. Openlabel pilot study of testosterone patch therapy in men with opioid-induced androgen deficiency. J Pain; 7:200-210.

[14] Facchinetti F, Comitini G, Petraglia F, Volpe A, Genazzani AR 1986. Reduced estriol and dehydroepiandrosterone sulphate plasma levels in methadone-addicted pregnant women. Eur J Obstet Gynecol Reprod Biol; 23:67-73.

[15] Rajagopal A, Vassilopoulou-Sellin R, Palmer JL, Kaur G, Bruera E 2003. Hypogonadism and sexual dysfunction in male cancer survivors receiving chronic opioid therapy. J Pain Symptom Manage; 26:1055-1061.

[16] Bliesener N, Albrecht S, Schwager A, Weckbecker K, Lichtermann D, Klingmuller D 2005. Plasma testosterone and sexual function in men receiving buprenorphine maintenance for opioid dependence. J Clin Endocrinol Metab; 90:203-206.

[17] Woody G, McLellan AT, O'Brien C, Persky H, Stevens G, Arndt I, Carroff S 1988. Hormone secretion in methadonedependent and abstinent patients. NIDA Res Monogr; 81:216-223. 